\title{
Ocular trauma at the Botucatu medical school
}

\author{
Trauma ocular na Faculdade de Medicina de Botucatu
}

Felipe de Queiroz Tavares Ferreira1 ${ }^{1}$, Marjorie Fornazier do Nascimento ${ }^{1}$, Roberta Lilian Fernandes de Sousa Meneguim¹, Carlos Roberto Padovani², Silvana Artioli Schellini ${ }^{1}$

\begin{abstract}
Purpose: To evaluate serious eye trauma requiring admission for treatment at a university hospital. Methods: This was a retrospective study involving 303 patients with severe ocular trauma who required hospitalization at the Hospital of the Faculty of Medicine of Botucatu - Unesp, from January 1998 to December 2008. Demographic data were evaluated and also the causes of accidents, factors involved, initial and final visual acuity (VA) as well as the procedures performed. Data were statistically analyzed. Results: Three hundred and seven severe eye traumas were admitted for surgery, most commonly affecting subjects between the ages of 26 and $40(26 \%)$ who were male (82\%). The trauma affecting adults occurred due to work or traffic accidents and in children, during leisure time or in the domestic environment. The cornea $(75 \%)$ and area I $(82 \%)$ was the most affected place. A penetrating trauma was most frequent, and the main causal agent was glass (18\%), mainly affecting farmers (41\%). The majority of the affected patients were not wearing protective equipment at the time of the ocular trauma. After surgery, the AV remained below 0.1 in $48 \%$ of affected individuals. The time between trauma and treatment influenced the visual prognosis. Conclusion: Severe eye trauma remains an important cause of morbidity and preventable monocular blindness. Although the severity of the ocular traumas, surgical treatment that is well conducted can minimize the damage to visual function and should reinforce the need for preventive measures.
\end{abstract}

Keywords: Eye injuries/epidemiology, Eye injuries/therapy; Prognosis

\section{ReSUMO}

Objetivo: Avaliar os traumas oculares graves atendidos em um hospital universitário e que demandaram internação. Métodos: Estudo retrospectivo envolvendo 303 portadores de trauma ocular grave atendidos no Hospital das Clínicas da Faculdade de Medicina de Botucatu - UNESP, entre Janeiro de 1998 até Dezembro de 2008 e que necessitaram internação. Foram avaliadas as variáveis demográficas, as causas dos acidentes, os fatores envolvidos, a acuidade visual inicial e final, assim como os procedimentos realizados. Os dados foram submetidos à análise estatística. Resultados: No período ocorreram 307 traumas oculares graves que foram internados e operados, com maior frequência entre 26 e 40 anos de idade (26\%) e do sexo masculino (82\%). A maioria dos casos entre os adultos decorreu de acidentes de trabalho ou de trânsito e em crianças, em ambiente de lazer ou doméstico. A córnea foi o local mais afetado $(75 \%)$ e a zona I foi a mais atingida $(82 \%)$. O trauma perfurante foi o mais frequente e o agente causal principal foi o vidro (18\%), acometendo principalmente os lavradores (41\%). A grande maioria dos portadores de trauma ocular atendidos não usava equipamentos de segurança. Após a cirurgia, a AV se manteve abaixo de $0,1 \mathrm{em} 48 \%$ dos acometidos. O tempo entre o trauma e o tratamento influenciou o prognóstico visual. Conclusão: $\mathrm{O}$ trauma ocular grave permanece como uma importante causa de morbidade e cegueira monocular prevenível. O tratamento cirúrgico bem conduzido pode minimizar o prejuízo para a função visual, devendo ser reforçada a necessidade de medidas de prevenção.

Descritores: Traumatismos oculares/epidemiologia; Traumatismos oculares/terapia; Prognóstico

\footnotetext{
${ }^{1}$ Departamento de Oftalmologia, Faculdade de Medicina de Botucatu, Universidade Estadual Paulista "Júlio de Mesquita Filho", Botucatu, SP, Brasil.

2 Departamento de Bioestatística, Instituto de Biociências de Botucatu, Universidade Estadual Paulista "Júlio de Mesquita Filho", Botucatu, SP, Brasil. Study conducted in Faculdade de Medicina de Botucatu, Universidade Estadual Paulista "Julio de Mesquita Filho", Botucatu, SP, Brasil.

The authors declare no conflicts of interests.

Received for publication 16/01/2016 - Accepted for publication 25/02/2016.
} 


\section{INTRODUCTION}

$\mathbf{E}$ ye trauma is the most important cause of unilateral visu al loss, but about $90 \%$ of injuries are preventable. The mostly affected age group is the productive one, leading to important economic and social consequences. According to the World Health Organization, the world annual frequency of ocular trauma is about 55 million per year, each of which interfering in labor activities for at least one day. ${ }^{1}$

In the world, about 750,000 individuals affected by eye trauma require hospitalization, and the trauma is responsible for 1.6 million blinds, 2.3 million individuals with low visual acuity, and 19 million with blindness or unilateral low vision. ${ }^{1}$

The most frequent cause of loss of the eyeballs between 0 and 10 years of age is eye trauma, with $58.04 \%$ of which occurring in domestic environments and being preventable. ${ }^{2}$

Both in developed and underdeveloped countries, the eye trauma due to traffic accident and occupational accidents prevail in adults and young adults, especially in men. The vast majority of traumas occur due to lack of preventive measures, such as seat belts and use of personal protective equipment. ${ }^{3-5}$

The University Hospital at Faculdade de Medicina de Botucatu is a reference to eye care of extensive territorial area and serves a large number of patients with ocular trauma.

The objective of this study is to evaluate the main causes of severe ocular trauma requiring hospitalization at this service, as well as the characteristics of the patients, assessing physical and social characteristics involved in these traumas.

\section{MethodS}

Retrospective study involving 303 patients treated at Hospital das Clínicas da Faculdade de Medicina de Botucatu-UNESP in the period from January 1998 to December 2008. All individuals enrolled in the present study suffered from severe trauma, that is, patients suffering from ocular trauma requiring urgent or emergency eye surgery, considering traumas not requiring hospitalization an exclusion criterion. Among the 303 patients with severe ocular trauma, 307 affected eyes have been detected, namely the trauma was bilaterally in four of them. The variables assessed were: age group ( 0 to 10 years old, 11 to 25 years old, 26 to 40 years old, 41 to 55 years and over 55 years old), gender, profession, environment in which experienced the trauma (work, home, leisure, car accident or physical assault), material causing the injury, use of safety belt in traffic accidents or personal protective equipment (PPE) due to work accidents. The abuse of alcohol and/or drugs at the time of trauma was also evaluated.

Factors related to care service, such as time elapsed between trauma and care service and between care service and surgical approach were also considered.

Visual acuity (VA) was assessed in primary care, one month after surgery and lately.

The classification of the injury was done according to Pieramici et. al. ${ }^{6}$ (zone I - lesions limited to the conjunctiva, sclera and cornea; zone II - involvement of structures of the anterior segment (iris and crystalline lens) and zone III - posterior segment involving internal and posterior structures to the posterior capsule of the crystalline; vitreous, retina and choroid).

The classification of Kuhn etal.7 was also used to classify the trauma as open (piercing, penetrating, rupture, intraocular foreign body) or closed (contusion and lamellar laceration).
The surgical treatment carried out was specified as: cornealscleral suture, facectomy, iris hernia treatment, removal of intraocular foreign body, eyelid suture, lacrimal duct reconstruction, ocular evisceration, enucleation and other approaches (vitrectomy, corneal transplant, etc.).

Data was retrieved from the medical records, transferred to Excel table and statistically analyzed using descriptive analysis by the adhesion test of chi-square, the non-parametric KruskalWallis test complemented by Dunn test, and the ratio test.

\section{RESULTS}

During the study period there were 307 eye injuries in 303 patients who required hospitalization and surgery, i.e., about 30 cases were treated per year, affecting more often male individuals ( $82 \%)$ between 26 and 55 years (43\%) (Figure 1).

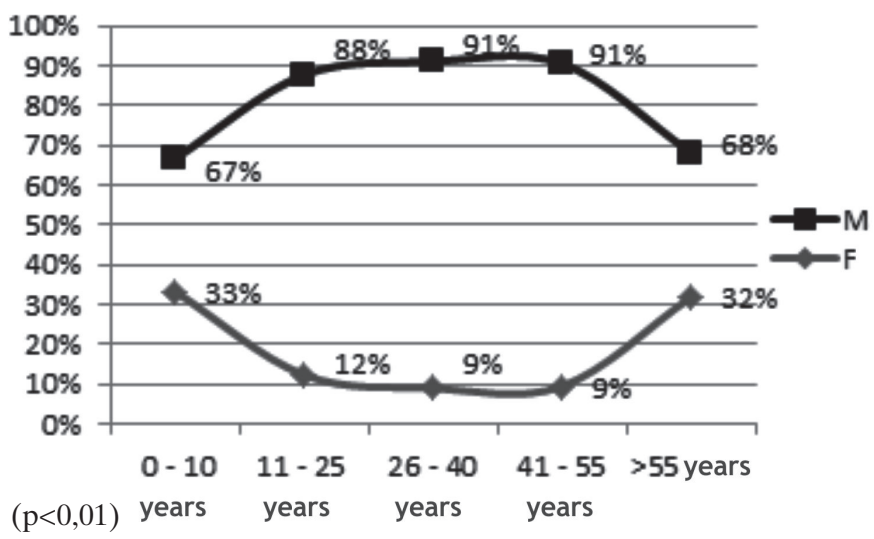

Figure 1. Distribution of severe ocular trauma patients treated at Faculdade de Medicina de Botucatu according to age group and gender

Regarding the place of occurrence of ocular trauma, in most cases it resulted from accidents at work (31\%), followed by traffic accidents $(28 \%)(\mathrm{p}<0.05)$. In the age group from 0 to 10 years, accidents at leisure environment were prevalent in $63 \%$, accompanied by domestic environment (25\%). In the age group from 11 to 25 years, the vast majority consisted of traffic accidents, followed by work accidents and physical attacks, respectively, $17 \%, 16 \%$ and $8 \%(\mathrm{p}<0.05)$ (Figure 2$)$.

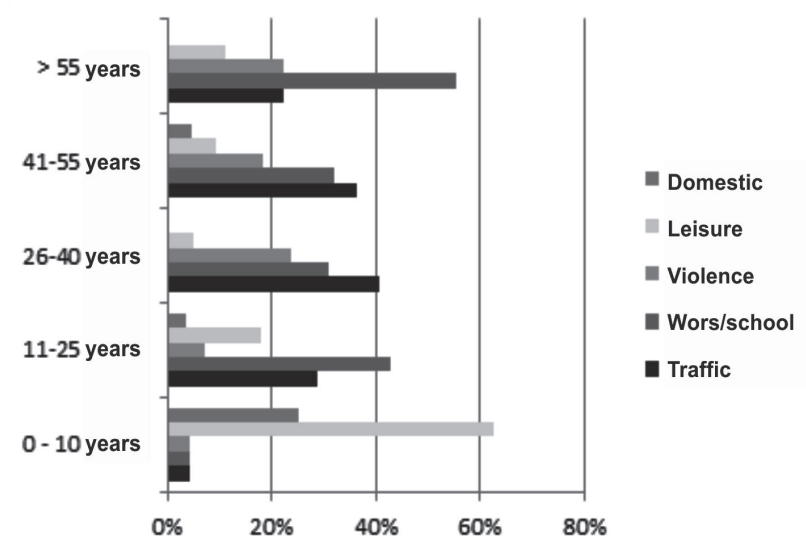

Figure 2. Distribution of severe eye injuries treated at Faculdade de Medicina de Botucatu according to location of the event and age group 
The most frequent ocular structure was the cornea (involved in $75 \%$ of trauma), with other regions affected in descending order: sclera $(31 \%)$, crystalline $(27 \%)$, iris $(24 \%)$, vitreous $(21 \%)$, retina $(16 \%)$, choroid $(16 \%)$, with concomitant involvement of the eyelid (14\%) or lacrimal canaliculus $(13 \%)$. Zone I was the most affected (82\%), followed by zone II (42\%), and finally zone III (28\%).

Consequently, the surgery mostly performed was the corneal-scleral suture, having been carried out 225 corneal-scleral sutures, with $10 \%$ requiring resuture, and $26 \%$ requiring other surgical procedures. Then the surgery mostly carried out was the reduction or resection of herniated iris $(20 \%)$. Facectomy was needed as a second procedure in $17 \%$ of cases, as well as other surgeries employed in 65 cases.

The time between eye trauma and care service took an average of 133 hours, and the time between the first care and the surgery was 31 hours.

Penetrating trauma was the most frequent, occurring in 199 cases.

The most frequent causal agent was glass $(18 \%)$, followed by metals and aluminum (13\%).

Eye trauma involved mainly the farmers (41\%), followed by the masons (25\%) (Figure 3 ).

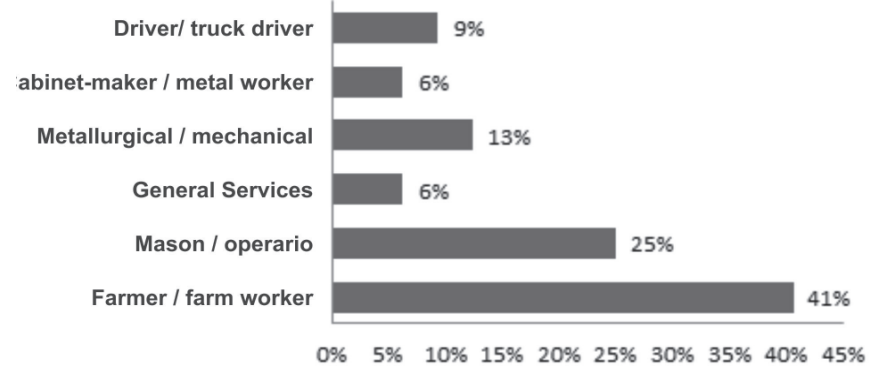

Figure 3. Distribution of severe ocular trauma treated at Faculdade de Medicina de Botucatu according to profession

The use of PPE is not common in patients with eye trauma, which could be seen by the analysis of our cases, when $100 \%$ of accidents in the workplace were not using PPE. In ocular trauma related to traffic accidents, it has been reported that only $6 \%$ of victims made use of the seat belt. The abuse of alcohol and/or drugs associated to eye trauma was reported in $7 \%$ of cases, being associated to $29 \%$ of the victims of traffic accidents and $21 \%$ of the victims of violence.

The VA many times was not obtained in the initial care. However, in $61 \%$ in which this information was present, $66 \%$ had VA $<0.1$ by Snellen, $16 \%$ between $0.1 \leq \mathrm{VA} \leq 0.4$, and $18 \%$ with $\mathrm{VA} \geq 0.5$. After surgery, the VA remained below 0.1 in $48 \%$ of patients, in $23 \% 0.1 \leq \mathrm{VA} \leq 0.4$ and $29 \% \mathrm{VA} \geq 0.5$ (Figure 4 ).

It was observed that when the initial VA was around 0.5 , the lesions generally affected zone I and/or zone II (conjunctiva, cornea, sclera, iris and crystalline), and these were the individuals who presented the best final VA. Injuries in zone III corresponded to $28 \%$ of traumas and presented a worse visual prognosis, usually with final VA below 0.1 . The group with initial VA of negative light perception (PL-) presented bad visual prognosis, obviously keeping the final VA of PL- in $100 \%$, being usually injuries affecting all plans, even the posterior pole, i.e., zone III (Figure 5).

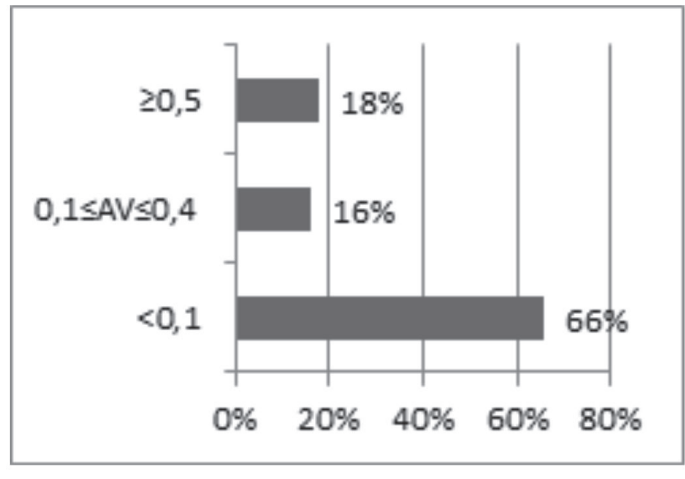

$(\mathrm{p}<0,01)$

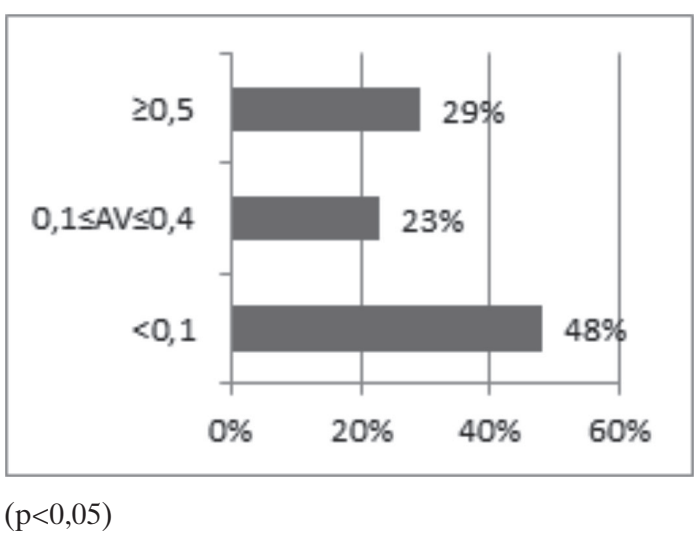

Figure 4. Distribution of severe ocular trauma treated at Faculdade de Medicina de Botucatu according to visual acuity in the first care and at the end of treatment

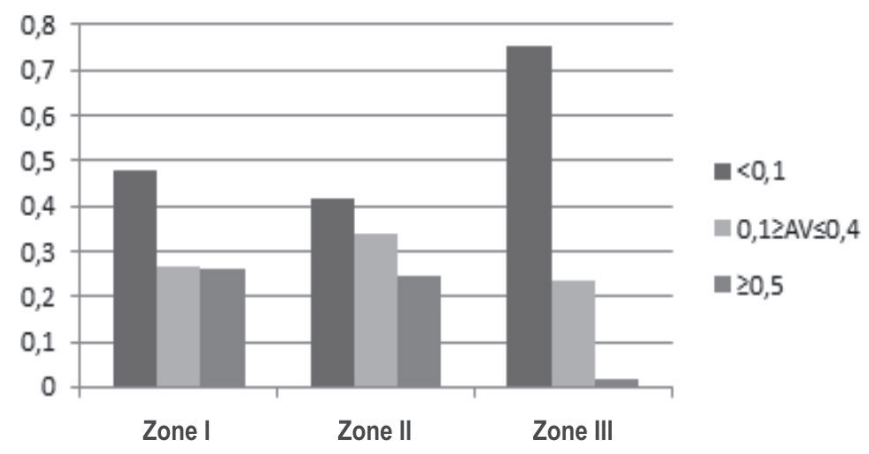

Figure 5. Distribution of eye trauma according to the region of involvement and final visual acuity.

The final VA remained equal to the initial in $58 \%$ of patients, with improvement in relation to the initial VA in $39 \%$ of the patients. $(p<0.05)$

The time between the moment of the trauma and the initial care showed correlation in the visual prognosis, as well as the time from initial care to surgery. Patients with final VA $<0.1$ took on average 127 hours before the initial care, and 76 hours from the initial care to the surgical procedure, whereas patients with final VA $\geq 0.5$ had on average 49 hours from trauma until the initial care, and on average 17 hours from initial care to the surgery (Table 1). 
Table 1

Distribution of eye traumas according to the final VA from time of trauma until the initial care and until surgery

\begin{tabular}{lcccc}
\hline & \multicolumn{3}{c}{ Final visual acuity } \\
\hline Time until care service in hours & $<\mathbf{0 . 1}$ & $\mathbf{0 . 1} \mathbf{- 0 . 3}$ & $>\mathbf{0 . 3}$ & $\boldsymbol{p}$ Value \\
Average; (standard deviation) & $127.3(284.9)$ & $126.0(589.2)$ & $48.7(59.3)$ & 0,337 \\
Median (min. value; max value) & $24.0(1 ; 2160)$ & $6.0(1 ; 3600)$ & $17.0(1 ; 144)$ & $<0,001$ \\
Time until surgery in hours & $<\mathbf{0 . 1}$ & $\mathbf{0 . 1} \mathbf{- 0 . 3}$ & $>\mathbf{0 . 3}$ & $\boldsymbol{p}$ \\
Average; (standard deviation) & $76.4(171.1)$ & $36.4(55,4)$ & $41.1(55.5)$ & $<0.001$ \\
Median (min. value; max value) & $10.5(2 ; 1440)$ & $8.0(2 ; 140)$ & $13.0(1 ; 140)$ & $>0.05$ \\
\hline
\end{tabular}

\section{DISCUSSION}

In the present study, there was a predominance of severe eye trauma men, in agreement with the literature that always shows men as the most affected. ${ }^{2,8-10}$

The age group seen here as the most frequent, between 26-55 years, points to the socioeconomic impact of the trauma, because it is an economically active age group and generally responsible for family income.

Work accidents were the predominant (31\%), closely followed by car accidents $(28 \%)$, a similar number to those of other studies, highlighting the exposure of individuals to traumas which can be preventable with simple measures that should be used routinely, as the use of safety belt and PPE.,9,11,12

The abuse of alcohol and/or drug associated with ocular trauma was reported in $7 \%$ of our cases, mainly from traffic accident victims (29\%) and violence (21\%), which raises the issue that awareness of the population is an important factor for prevention. Despite laws and various mass campaigns implemented by the traffic control authorities in the country, there are still a high frequency of car accidents in which there was no use of safety belt and many cases related to alcohol use.

The materials causing most ocular traumas were glass and metals in general, which has a positive correlation with the type of accident - traffic and work.

Farmers are the most affected profession, which is compatible with the profile of our region, where rural activities are dominant. Traumas in agriculture are often serious, besides going along with the lack of knowledge or low access to PPE and poorer health care.

Studies on eye injuries often cannot be compared by the use of different classifications and definitions. We use the ratings of Kunh et.al. ${ }^{7}$ and Pieramici et.al. ${ }^{6}$. Besides providing a greater opportunity to compare data, these ratings also embed the opportunity to assess the severity of the trauma, pointing to prognostic factors even before the surgical approach.

The most frequent severe trauma was perforation, with the cornea being the most affected area, and the corneal-scleral suture the surgery most frequently performed. After the first approach, there may be need for other surgical procedures, as we observed in several patients. The first surgeries have as main objective the closing of the eyeball with "watertight", i.e., no leakage of aqueous humor and the least distortion of the tissue possible ${ }^{2}$, besides isolating the intraocular structures from the external environment, preventing infections. A second surgical procedure is usually necessary for better visual rehabilitation, such as facectomy and corneal transplants, surgeries for which the ophthalmologist who cares for eye traumas should be prepared.

Ocular trauma is a cause of visual impairment and blindness worldwide, always emphasizing the need to use preventive measures which could reduce significantly the socio-economic and personal impacts. ${ }^{4,9,11,12}$

In general hospitals, open eye traumas do not constitute an emergency, since they do not threaten the life of the victim. However, it has an emergency character because they require a quick approach, which avoids exposure of intraocular materials and influence the visual prognosis, as we have seen, reducing complications such as endophthalmitis, cystoid macular edema, etc. ${ }^{2,13}$

\section{Conclusion}

Severe eye trauma remains an important cause of morbidity and preventable monocular blindness. The wellconducted surgical treatment can minimize the damage to visual function, but the need for preventive measures should be strengthened, such as the use of seat belts and PPE, avoiding the abuse of alcohol while driving, besides awareness and quick search for specialized medical care. Preventive measures such as these are known to have strong impact on the visual health.

\section{RefERENCES}

1. Negrel AD, Thylefors N. The global impact of eye injuries. OphthalmicEpidemiol. 1998; 5(3):143-69.

2. Barbi JSF, Figueiredo ARP, Turrer CL, Bevilacquia ER. Análise da frequência de trauma ocular em pacientes de 0-10 anos no setor de plástica ocular do Hospital São Geraldo. RevMed Minas Gerais. 2009; 19(2):127-31.

3. Takahashi WY. Traumatismos e emergências oculares. 5aed. São Paulo: Roca, 2003. p. 1-6; 131-52. 
4. Thompson GJ, Mollan SP. Occupational eye injuries: a continuing problem. Occup Med. 2009; 59(2): 123-25.

5. Silber PC, Souza LB, Tongu MTS. Perfil epidemiológico do trauma ocular penetrante antes e após o novo código de trânsito. ArqBrasOftalmol. 2002; 65(4):441-4.

6. Pieramici DJ, Sternberg P, Aaberg TM, Bridges WZ Jr, Capone A $\mathrm{Jr}$, Cardillo Ja, et al. A system for classifying mechanical injuries of the eye (globe). The Ocular Trauma Classification Group. Am J Ophthalmol. 1997; 123(6):820-31.

7. Kuhn F, Morris R, Whitherspoon D, Heimann K, Jeffers JB, Treister G. A standardized classification of ocular trauma. Ophthalmology. 1996; 103(2): 240-3.

8. Teixeira SM, Bastos RR, Falcão MS, Falcão-Reis FM, RochaSousa AA. Open-globe injuries at an emergency department in Porto, Portugal: clinical features and prognostic factors. Eur J Ophthalmol. 2014;24(6): 932-9.

9. Semeraro F, Polcini C, Forbice E, Monfardini A, Costagliola C, Apostoli P. Work- and non-work-related eye injuries in a highly industrialized area in northern Italy: comparison between two three-year periods (1994-1996 and 2005-2007). Med Lav. 2013;104(6):467-75.
10. Cheung CA, Rogers-Martel M, Golas L, Chepurny A, Martel JB, Martel JR. Hospital-based ocular emergencies: epidemiology, treatment, and visual outcomes. Am J Emerg Med. 2014; 32(3):221-4.

11. Kuhn F, Morris R, Whiterspoon CD, Mann L. Epidemiology of blinding trauma in the United States Eye Injury. OphthalmicEpidemiol. 2006; 13(3)209-16.

12. Balaghafari A, Siamian H, Aligolbandi K. Ocular trauma: 2 years of retrospective study in Sari, Iran. MaterSociomed. 2013; 25(4):230-2.

13. Ryan DS, Sia RK, Colyer M, Stutzman RD, Wroblewski KJ, Mines MJ, Bower KS. Anterior segment imaging in combat ocular trauma. J Ophthalmol. 2013; 2013: 308259.

\section{Corresponding author:}

Felipe de Queiroz Tavares Ferreira

Rua Azaléia, 930, AP. 14 - Botucatu (SP) - 18603-550 - Brasil

E-mail: felipeqtf@hotmail.com 